\title{
Comparison of the microbial and nutritional quality characteristics in radish sprouts by purchasing time
}

\author{
Jin Ju Park, Hye Jeong Yang, Kyu-Jai Han, Jeong-Ho Lim* \\ Korea Food Research Institute, Seongnam 463-746, Korea
}

\section{무 새쌕채소의 구매시기에 따른 미생물 및 영양학적 품질특성 비교}

\author{
박진주 · 양혜정 · 한규재 · 임정호* \\ 한국식품연구원
}

\begin{abstract}
This study investigated the microbiological and nutritional characteristics of bimonthly radish sprouts purchased at a local market. The total bacteria and coliform measurements were highest in summer (June and August) and lowest in winter (February and December). The total phenol content was $16.82 \pm 0.69 \mathrm{GAE} \mathrm{mg} / \mathrm{g}$, and it did not significantly differ during the investigation period. The total carotenoid contents were highest in February (about 12.81 $\pm 0.49 \beta$-carotene $\mathrm{mg} / \mathrm{g}$ ) and lowest in April (about 8.09 $\pm 1.01 \beta$-carotene $\mathrm{mg} / \mathrm{g}$ ). However although total glucosinolates content differ between the total crude glucosinolate and the sum of the individual glucosinolates, it was highest in December. The individual glucosinolates were found to have been gucoraphenin, glucoerucin, glucobrassicin and gluconasturtiin in radish sprouts via HPLC analysis. The purchasing time of the glucoraphenin content did not significantly differ. The measured glucoerucin was highest in February and lowest in October. The gucobrassicin and gluconasturtiin were higher in summer than in winter, but did not significantly differ. The antioxidant activity (i.e., the $\mathrm{IC}_{50}$ values of the DPPH radical scavenging) was highest in February. In conclusion, the microbial contamination, total carotenoids, and antioxidant activity changed according to the purchasing season, but the total phenolic compounds and total glucosinolates were maintained regardless of the time in the radish sprouts.
\end{abstract}

Key words : radish sprouts, seasonal, microbial, glucosinolate, antioxidant activity

\section{서 론}

새싹채소는 간편하고 건강한 식단을 지향하는 현대인들 사이에서 널리 이용되는 신선편의식품 중 하나이며, 브로 콜리싹, 메밀싹, 무싹, 콜라비싹, 알팔파싹 등이 주로 이용 되고 있다 $(1,2)$. 새싹채소는 완전한 성장을 위해 영양소 및 식물 생리활성물질을 생합성하는 시기에 이용되는 채소를 의미하며, 종자나 완전히 성숙한 채소보다 높은 생리활성 물질을 가진다고 보고되어 있다(3-6). 새싹채소로 널리 이

*Corresponding author. E-mail : jhlim@kfri.re.kr Phone : 82-31-780-9331, Fax : 82-31-780-9333

Received 16 December 2014; Revised 30 January 2015; Accepted 3 February 2015.

Copyright (c) The Korean Society of Food Preservation. All rights reserved.
용되고 있는 십자화과 식물은 글루코시놀레이트와 페놀성 화합물 등이 다량 함유되어 있는 것으로 알려져 있다. 그 중 특유의 맛과 향을 가지고 있어 샐러드나 곁들이 음식 등으로 이용되는 무 새싹채소는 항암물질로 알려진 인돌계 화합물, 비타민 및 $\mathrm{Ca}, \mathrm{P}, \mathrm{Fe}, \mathrm{Mg}$ 등의 알카리성 원소 등을 함유하여 그 영양학적 가치가 매우 높은 식품이다(7-10). 새싹채소에 대한 미생물적 오염에 대한 연구에서는 부적 절한 유통과정에 따른 위해 미생물의 위험성이 있으며(11), 특히, 총균수와 대장균수가 비교적 높게 검출되어(12), 식 중독의 위험성이 높은 식품으로 보고되고 있다(13). 또한 생산 기간별 콩나물에 대한 미생물 오염도를 측정한 결과에 서도 봄과 여름에서 미생물 오염도가 더 높은 것으로 보고 되었다(14). 그러나 생육기간이 5 7일정도로 짧고 실내에 서 재배가 가능하여 사계절 내내 수확되고 유통되어지고 있는 무 새싹채소에 대한 미생물 및 영양학적인 품질 평가 
에 대한 연구는 미미한 수준이다.

따라서 본 연구에서는 연중 생산·유통되는 무 새싹채소 의 미생물 및 영양학적 품질 변화를 조사하기 위하여 2 개월 마다 시료를 구입하여 미생물적 품질지표로서 총균수 및 대장균군수를 측정하였고, 영양학적 품질지표로서 총 페 놀, 총 카로티노이드, 총 글루코시놀레이트, 개별 글루코시 놀레이트 및 항산화 활성을 조사하였다.

\section{재료 및 방법}

\section{재 료}

2012년 12월부터 2013년 10월까지 경기도 성남의 대형 마트, 백화점 및 온라인 쇼핑몰 등을 통해 생산자가 다른 5 종류(RS1 RS5)의 무 새싹채소를 두 달 간격으로 구입하 였다. 시료의 일부는 즉시 총균수와 대장균군의 오염도를 알아보는데 사용하였고, 나머지 시료는 액체질소로 동결시 켜 동결건조기(FD8508, Ilshin Lab Co., Ltd., Yangju-si, Gyeonggi-do, Korea)를 이용하여 건조하였다. 건조된 시료 는 분쇄 후 60 메쉬 체에 쳐서 시료로 이용하였으며, 분쇄한 시료는 $4^{\circ} \mathrm{C}$ 의 냉장실에 보관하면서 실험에 이용하였다.

\section{추 출}

동결건조 된 시료 $0.2 \mathrm{~g}$ 에 10 배에 해당하는 $80 \%$ 에탄올을 가한 후, $30^{\circ} \mathrm{C}$ shaking incubator(JSSI-100C, JSR Co., Gongju, South Chungcheong Province, Korea)에서 $150 \mathrm{rpm}$ 으로 18 시간 동안 추출하였다. 이 과정을 3 회 반복 추출하여 모아진 추출액은 여과지(Whatman No. 2)로 여과하여 회전 식 증발농축기(Rotavapor R-205, Buchi, Flawil, Swizerland) 로 감압농축한 후, $80 \%$ 에탄올로 $50 \mathrm{~mL}$ 의 메스플라스크에 정용하여 이를 추출액으로 사용하였다.

\section{총 균수 및 대장균군수}

생시료 $10 \mathrm{~g}$ 을 멸균백에 담아 $0.85 \%$ 멸균 생리식염수 용액 $90 \mathrm{~mL}$ 를 넣고 stomacher(400 Circulator, Seward, West Sussex, England)로로 균질화 시킨 후, 10 배씩 단계적으로 희석시켜 배지에 분주하였다. $37^{\circ} \mathrm{C}$ 배양기에서 48 시간 배 양한 뒤, 형성된 colony를 계수하여 시료 당 colony forming unit(CFU)의 수치로 나타내었으며, 총 균수는 plate count agar(PCA, BD Difco, Franklin Lakes, New Jersey, USA) 배 지, 대장균군수는 chromocult(VM659026 435, Merck Co., Darmstadt, Germany) 배지를 사용하였다.

\section{총 페놀}

시료의 총 페놀 함량은 Folin-Ciocalteus법(15)에 따라 함 량을 측정하였다. 시료 $0.5 \mathrm{~mL}$ 에 $1 \mathrm{~N}$ Folin-Ciocalteus 시약 을 $0.5 \mathrm{~mL}$ 첨가하고, $2 \%$ sodium carbonate anhydrous 포화용
액 $10 \mathrm{~mL}$ 를 첨가하여 1 시간 동안 반응시킨 후 흡광도를 측정하였다. 흡광도는 $750 \mathrm{~nm}$ 에서 UV-spectrophotometer (V-570, Jasco Co., Tokyo, Japan)로 측정하였으며, 표준물질 로는 gallic acid(Sigma Chemical Co., Louis, MO, USA)를 사용하였다.

총 카로티노이드

시료의 카로티노이드 함량은 $\mathrm{Kim}$ 등(16)의 방법을 이용 하여 측정하였다. 동결 건조한 시료 $0.2 \mathrm{~g}$ 에 $0.1 \% \mathrm{BHT}$ 를 포함하는 에탄올 $6 \mathrm{~mL}$ 를 혼합하여 $85^{\circ} \mathrm{C}$ 드라이오븐에서 5 분간 예열시키고, $80 \% \mathrm{KOH} 120 \mu \mathrm{L}$ 를 첨가하여 $85^{\circ} \mathrm{C}$ 드라 이오븐에서 10 분 동안 반응시킨 다음, 상온에서 냉각시켰 다. 여기에 증류수와 hexane 용액을 각각 $3 \mathrm{~mL}$ 씩 첨가하여 섞어주고 원심분리 $(3,500 \times \mathrm{g}, 15 \mathrm{~min})$ 하여 상층액만 수집한 후, 남은 잔여물에 다시 증류수와 hexane 용액을 $3 \mathrm{~mL}$ 씩 첨가하고, 동일한 과정을 1 회 더 반복하여 수집된 상층액을 모아 질소농축 하였다. 질소농축한 건고물은 메탄올과 methyl tert-butyl ether(MTBE)를 1:1로 혼합한 용매에 녹여 $450 \mathrm{~nm}$ 에서 흡광도를 측정하였다. 분석에는 ELISA reader(680, Bio-rad, Hercules, CA, USA)를 사용하였으며, 표준물질로는 $\beta$-carotene(Sigma Chemical Co.)을 사용하였 다.

총 글루코시놀레이트

총 글루코시놀레이트는 $\operatorname{Kestwal}(17)$ 의 방법을 이용하여 측정하였다. 추출액은 동결 건조된 시료 $0.1 \mathrm{~g}$ 에 $99 \%$ 에탄 올 $3 \mathrm{~mL}$ 를 넣고 $30^{\circ} \mathrm{C}$ 에서 $100 \mathrm{rpm}$ 으로 20 시간동안 교반하 여 추출한 다음 상층액을 여과지(Whatman, No.1)로 여과한 것과 남은 잔여물에 $99 \%$ 에탄올 $3 \mathrm{~mL}$ 를 넣어 1 분간 교반한 후 여과한 것을 모아서 실험에 사용하였다.

96-well cell culture plate(SPL)에 추출액 $20 \mu \mathrm{L}$ 와 $2 \mathrm{mM}$ sodium tetrachloropalladate solution $300 \mu \mathrm{L}$ 를 넣어 실온에서 30 분간 반응시킨 후, $450 \mathrm{~nm}$ 에서 ELISA reader로 흡광도를 측정하여 함량을 계산하였다. 표준물질로는 sinigrin hydrate (Sigma Chemical Co.)를 사용하였다.

\section{개별 글루코시놀레이트}

Chung(18)의 방법을 변형하여 무 새싹채소에 함유된 글 루코시놀레이트의 정성 및 정량분석을 실시하였다. 동결 건조된 시료 $0.2 \mathrm{~g}$ 에 메탄올 $4 \mathrm{~mL}$ 를 첨가하여 $70^{\circ} \mathrm{C}$ 항온 수조에서 15 분간 교반 추출한 후 실온으로 냉각시킨 추출 물의 상층액을 여과지(Whatman No.2)로 여과하였다. 여과 후 남은 잔여물에 메탄올 $2 \mathrm{~mL}$ 을 넣고 교반하여 여과하는 과정을 2 회 반복한 후, 여과된 추출액을 모아 $55^{\circ} \mathrm{C}$ 에서 질소 농축 시켰으며, 건고물을 메탄올 $2 \mathrm{~mL}$ 로 녹여 실험용액으 로 사용하였다.

Teflon frits $(6 \mathrm{~mL}$, Supelco, Sigma-Aldrich, Louis, MO, 
USA)로 양 끝을 막은 syringe에 $200^{\circ} \mathrm{C}$ 에서 overnight시켜 활성화시킨 florisil sorbent를 $0.8 \mathrm{~g}$ 담아 제작한 column에 $30 \%(\mathrm{v} / \mathrm{v})$ dichloromethane을 포함하는 hexane 용액을 흘려 씻어주었다. 여기에 추출한 시험용액 $300 \mu \mathrm{L}$ 를 $30 \%(\mathrm{v} / \mathrm{v})$ dichloromethane을 포함하는 hexane 용액 $5 \mathrm{~mL}$ 와 섞어 통과 시킨 후, 30\%(v/v) dichloromethane을 포함하는 hexane 용액 $5 \mathrm{~mL}$ 를 다시 흘려주었다. 마지막으로 $30 \%$ ethyl acetate를 포함하는 메탄올 용액 $5 \mathrm{~mL}$ 를 흘려 정제된 것을 모아 $50^{\circ} \mathrm{C}$ 에서 질소농축한 뒤, 건고물에 $\mathrm{HPLC}$ 용 증류수 $300 \mu \mathrm{L}$ 를 첨가하여 녹인 것을 $0.45 \mu \mathrm{m}$ syringe filter(PVDF, Whatman, England)로 여과하여 분석 시료로 사용하였다.

분석기기는 HPLC(Nano 2D LC system, shimadzu, Kyoto, Japan)를 이용하였으며, column은 Intersil ODS2 $\left(\mathrm{C}_{18}\right)$ column(4.6×250 mm, GL Science, Tokyo, Japan), 이동상으 로는 (A) formic acid가 첨가된 $30 \mathrm{mM}$ ammonium acetate $(\mathrm{pH}$ 5.0)와 (B) 메탄올을 이용하였다. 분석시간은 총 40 분으 로, 처음 5 분은 $(\mathrm{A})$ 를 $100 \%$ 로, 그 다음 12 분 동안 $(\mathrm{A})$ 를 $70 \%$ 까지 낮춘 다음 8 분간 유지하고 다시 5 분 동안 $(\mathrm{A})$ 를 $100 \%$ 로 높여준 다음 10 분간 유지하였다. 또한, flow rate는 $1 \mathrm{~mL} / \mathrm{min}$, injection volume은 $10 \mu \mathrm{L}$, 분석파장은 $233 \mathrm{~nm}$ 로 설정하였다. 표준물질로서 glucoiberin, gluconapin, glucoerucin은 ChromaDex ${ }^{\mathrm{TM}}$ (Muirland Blvd, IL, USA)에서 구입하였다. Progoitrin, glucoraphanin, glucoraphenin, glucotropaeolin, glucobrassicin, gluconasturtiin은 Cfm Oskar Tropitzsch GmbH(Marktredwitz, Germany)에서 구입하였으 며, sinigrin은 Sigma Chemical Co.에서 구입하여 사용하였 다(Fig. 1).

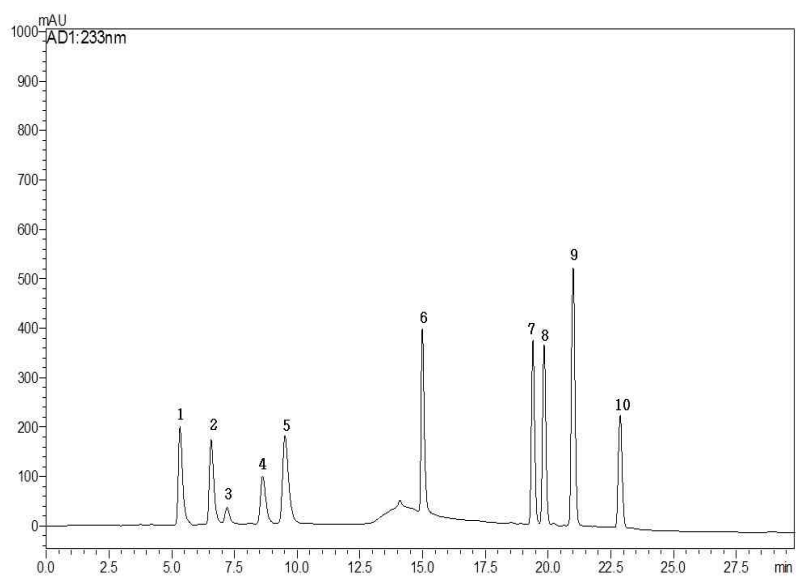

Fig. 1. HPLC chromatogram of the glucosinolate standard compounds.

1, glucoiberin (RT 5.32); 2, progoitrin (RT 6.56'); 3, sinigrin (RT 7.19'); 4, glucoraphanin (RT 8.62'); 5, glucoraphenin (RT 9.50'); 6, gluconapin (RT 14.98'); 7, glucotropaeolin (RT 19.39'); 8, glucoerucin (RT 19.83'); 9, glucobrassicin (RT 20.99'); 10, gluconasturtiin (RT 22.87'). RT means retention time.

\section{항산화 활성}

무 새싹채소의 항산화 활성은 Lee 등(19)의 방법을 참고
하여, 2,2-diphenyl- $\beta$-picrylhydrazyl(DPPH) 라디칼 소거능 을 측정하였다. 추출액을 단계적으로 희석하여 $4 \mathrm{~mL}$ cuvette에 $0.7 \mathrm{~mL}$ 씩 담고, $0.1 \mathrm{mM} \mathrm{DPPH}$ 용액 $2.8 \mathrm{~mL}$ 를 넣어 실온에서 30 분간 반응시킨 후, $517 \mathrm{~nm}$ 에서 흡광도를 측정하였다. 분석에는 UV-spectrophotometer를 이용하였으 며 대조구로는 $80 \%$ 에탄올을 이용하였고, 다음의 계산식을 이용하여 DPPH 라디칼 소거능(\%)을 계산하였다. 결과 값 은 $\mathrm{IC}_{50}$ 값으로 나타내었다.

DPPH radical scavenging activity(\%)

$$
=\left(1-\mathrm{Abs}_{\text {sample }} / \mathrm{Abs}_{\text {control }}\right) \times 100
$$

\section{통계처리}

본 실험의 통계적 분석은 $\mathrm{SAS}$ (Statistical Analysis System program, 8.2, SAS Institute Inc, Cary, NC, USA) 프로그램을 이용하였으며, $\mathrm{p}<0.05$ 수준에서 Duncan's multiple range test를 이용하여 각 처리구간의 유의성을 검증하였다.

\section{결과 및 고찰}

일반세균수 및 대장균군수 분석

구매시기에 따른 무 새싹채소의 일반세균수와 대장균군 수를 측정한 결과, 일반세균수는 평균값이 $6.39 \sim 8.22 \mathrm{log}$ $\mathrm{CFU} / \mathrm{g}$ 의 범위로 6 월에 가장 높고 12월에 가장 낮게 나타났 으며, 대장균군수는 평균값이 $6.01 \sim 7.36 \log \mathrm{CFU} / \mathrm{g}$ 로 일반 세균수와 마찬가지로 6 월에 가장 높고 12 월에 가장 낮았다 (Table 1, 2). 이러한 결과는 Kang(12)의 연구에서 새싹채소 의 총 호기성 균의 평균값이 $7.95 \log \mathrm{CFU} / \mathrm{g}$, 대장균군수의 평균값이 $6.69 \log \mathrm{CFU} / \mathrm{g}$ 으로 나타난 것과 유사한 값을 나타내며, Lee(20)가 무순의 일반세균수를 $7.3 \log \mathrm{CFU} / \mathrm{g}$, 대장균군수를 $5.5 \log \mathrm{CFU} / \mathrm{g}$ 으로 보고하고, $\mathrm{Jo}(21)$ 가 새싹 채소의 일반세균수를 8.0 8.9 $\log \mathrm{CFU} / \mathrm{g}$ 으로 보고한 것과 도 비슷하거나 높은 값을 나타내었다. 또한, Park(14)이 보 고한 여름 콩나물이 겨울보다 오염도가 높게 나타났던 결과 와도 비슷한 양상을 보인다. 이는 온도와 습도가 높은 계절 의 영향인 것으로 생각되며, 따라서 이런 결과로 미루어 볼 때 무 새싹채소의 생산 및 유통과정에서 겨울보다 여름 에 더 주의를 기울여야 할 것이다. 대장균군의 검출은 대장 균 및 병원성 균인 Shigella나 Salmonella 등이 검출될 가능 성을 의미하므로, 무 새싹채소의 생산 및 소비에서 병원성 미생물의 증식을 억제할 수 있는 다양한 수단이 필요할 것으로 판단되었다.

\section{총 페놀}

페놀성 화합물은 다양한 생리활성을 나타내는 것으로 알려져 있으며, 자유 라디칼을 소거시키는 것이 그 중 가장 
Table 1. Total bacteria levels of bimonthly and seasonal radish sprouts

\begin{tabular}{|c|c|c|c|c|c|c|c|}
\hline & & \multicolumn{6}{|c|}{ Total bacteria (log CFU/g) } \\
\hline & & $\mathrm{RS}^{1)}$ & RS2 & RS3 & RS4 & RS5 & Mean \\
\hline \multirow{7}{*}{ Month ${ }^{2}$} & Feb. & $7.64 \pm 0.07^{3 / 244)(B 5)}$ & $6.61 \pm 0.13^{\mathrm{dE}}$ & $7.26 \pm 0.14^{\mathrm{bD}}$ & $7.11 \pm 0.11^{\mathrm{cD}}$ & $6.42 \pm 0.23^{\mathrm{eD}}$ & $7.01 \pm 0.49^{\mathrm{B}}$ \\
\hline & Apr. & $7.50 \pm 0.10^{\mathrm{dBC}}$ & $7.60 \pm 0.11^{\mathrm{cB}}$ & $7.88 \pm 0.10^{\mathrm{bB}}$ & $8.09 \pm 0.09^{\mathrm{aB}}$ & $7.94 \pm 0.06^{\mathrm{bBC}}$ & $7.80 \pm 0.24^{\mathrm{A}}$ \\
\hline & Jun. & $8.17 \pm 0.13^{\mathrm{bcA}}$ & $8.34 \pm 0.23^{2 \mathrm{~A}}$ & $8.19 \pm 0.10^{\mathrm{abcA}}$ & $8.32 \pm 0.07^{\mathrm{abA}}$ & $8.08 \pm 0.13^{\mathrm{cAB}}$ & $8.22 \pm 0.11^{\mathrm{A}}$ \\
\hline & Aug. & $7.36 \pm 0.24^{\mathrm{cdC}}$ & $7.28 \pm 0.14^{\mathrm{dC}}$ & $7.53 \pm 0.28^{\mathrm{bcC}}$ & $7.68 \pm 0.16^{\mathrm{bC}}$ & $8.16 \pm 0.11^{\mathrm{aA}}$ & $7.60 \pm 0.35^{\mathrm{A}}$ \\
\hline & Oct. & $8.09 \pm 0.16^{\mathrm{aA}}$ & $6.88 \pm 0.25^{\mathrm{cD}}$ & $7.83 \pm 0.14^{\mathrm{bB}}$ & $7.81 \pm 0.11^{\mathrm{bC}}$ & $7.87 \pm 0.09^{\mathrm{bC}}$ & $7.70 \pm 0.47^{\mathrm{A}}$ \\
\hline & Dec. & $6.92 \pm 0.18^{\mathrm{aD}}$ & $5.59 \pm 0.20^{\mathrm{cF}}$ & $7.32 \pm 0.24^{\mathrm{bD}}$ & $6.76 \pm 0.28^{\mathrm{bE}}$ & $5.68 \pm 0.34^{6 \mathrm{E}}$ & $6.39 \pm 0.76^{\mathrm{C}}$ \\
\hline & Mean & $7.61 \pm 0.47^{\mathrm{a}}$ & $7.05 \pm 0.94^{\mathrm{a}}$ & $7.67 \pm 0.36^{\mathrm{a}}$ & $7.58 \pm 0.65^{\mathrm{a}}$ & $7.36 \pm 1.05^{\mathrm{a}}$ & $7.45 \pm 0.73$ \\
\hline \multirow{2}{*}{ Season } & Summer ${ }^{6}$ & $7.77 \pm 0.57^{\mathrm{A}}$ & $7.81 \pm 0.75^{\mathrm{A}}$ & $7.86 \pm 0.47^{\mathrm{A}}$ & $8.00 \pm 0.45^{\mathrm{A}}$ & $8.12 \pm 0.06^{\mathrm{A}}$ & $7.91 \pm 0.15^{\mathrm{A}}$ \\
\hline & Winter $^{7}$ & $7.28 \pm 0.51^{\mathrm{B}}$ & $6.10 \pm 0.72^{\mathrm{B}}$ & $7.29 \pm 0.04^{\mathrm{B}}$ & $6.79 \pm 0.46^{\mathrm{B}}$ & $6.05 \pm 0.52^{\mathrm{B}}$ & $6.70 \pm 0.61^{\mathrm{B}}$ \\
\hline
\end{tabular}

${ }^{11} \mathrm{RS} 1 \sim \mathrm{RS} 5$ refer to the names of the random sample group.

2)"Month" means the purchasing time.

${ }^{3)}$ The values are the mean \pm SD.

4)a-d Means in a row not followed by the same letter are significantly differ $(\mathrm{p}<0.05)$.

${ }^{5 \mathrm{~A}-\mathrm{E}}$ Means in a column row not followed by the same letter are significantly differ $(\mathrm{p}<0.05)$.

" "Summer" means June and August.

7)"Winter" means February and December.

Table 2. Coliform levels of bimonthly and seasonal radish sprouts

\begin{tabular}{|c|c|c|c|c|c|c|c|}
\hline & & \multicolumn{6}{|c|}{ Coliform (log CFU/g) } \\
\hline & & $\mathrm{RS}^{1)}$ & RS2 & RS3 & RS4 & RS5 & Mean \\
\hline \multirow{7}{*}{ Month $^{2)}$} & Feb. & $6.88 \pm 0.19^{3 / 344 / 35)}$ & $5.62 \pm 0.12^{\mathrm{dD}}$ & $6.35 \pm 0.38^{\mathrm{bC}}$ & $5.99 \pm 0.18^{\mathrm{cD}}$ & $5.98 \pm 0.09^{\mathrm{cD}}$ & $6.16 \pm 0.48^{\mathrm{BC}}$ \\
\hline & Apr. & $6.35 \pm 0.21^{\mathrm{dC}}$ & $7.19 \pm 0.11^{\mathrm{aB}}$ & $6.91 \pm 0.13^{\mathrm{bB}}$ & $6.49 \pm 0.18^{\mathrm{dBC}}$ & $6.68 \pm 0.12^{\mathrm{cC}}$ & $6.72 \pm 0.33^{\mathrm{B}}$ \\
\hline & Jun. & $7.34 \pm 0.24^{\mathrm{bA}}$ & $7.90 \pm 0.20^{\mathrm{aA}}$ & $7.38 \pm 0.20^{\mathrm{bA}}$ & $6.95 \pm 0.15^{\mathrm{cA}}$ & $7.21 \pm 0.16^{\mathrm{bA}}$ & $7.36 \pm 0.35^{\mathrm{A}}$ \\
\hline & Aug. & $6.25 \pm 0.18^{\mathrm{cC}}$ & $6.37 \pm 0.25^{\mathrm{cC}}$ & $6.28 \pm 0.29^{\circ \mathrm{C}}$ & $6.69 \pm 0.29^{6 \mathrm{~B}}$ & $7.01 \pm 0.15^{\mathrm{aB}}$ & $6.52 \pm 0.32^{\mathrm{BC}}$ \\
\hline & Oct. & $6.96 \pm 0.30^{a \mathrm{~B}}$ & $5.51 \pm 0.37^{\mathrm{cD}}$ & $7.05 \pm 0.16^{\mathrm{B}}$ & $6.56 \pm 0.25^{\mathrm{bB}}$ & $6.52 \pm 0.22^{\mathrm{bCD}}$ & $6.52 \pm 0.61^{\mathrm{BC}}$ \\
\hline & Dec. & $6.47 \pm 0.37^{\mathrm{aC}}$ & $5.19 \pm 0.18^{\mathrm{bE}}$ & $6.48 \pm 0.34^{\mathrm{aC}}$ & $6.29 \pm 0.31^{\mathrm{aC}}$ & $5.60 \pm 0.24^{6 \mathrm{E}}$ & $6.01 \pm 0.58^{\mathrm{C}}$ \\
\hline & Mean & $6.71 \pm 0.42^{\mathrm{a}}$ & $6.30 \pm 1.07^{\mathrm{a}}$ & $6.74 \pm 0.44^{\mathrm{a}}$ & $6.49 \pm 0.33^{\mathrm{a}}$ & $6.50 \pm 0.61^{\mathrm{a}}$ & $6.55 \pm 0.61$ \\
\hline \multirow{2}{*}{ Season } & Summer ${ }^{6}$ & $6.80 \pm 0.77^{\mathrm{A}}$ & $7.14 \pm 1.08^{\mathrm{A}}$ & $6.83 \pm 0.78^{\mathrm{A}}$ & $6.82 \pm 0.18^{\mathrm{A}}$ & $7.11 \pm 0.14^{\mathrm{A}}$ & $6.94 \pm 0.17^{\mathrm{A}}$ \\
\hline & Winter $^{7}$ & $6.68 \pm 0.29^{\mathrm{A}}$ & $5.41 \pm 0.30^{\mathrm{B}}$ & $6.42 \pm 0.09^{\mathrm{B}}$ & $6.14 \pm 0.21^{\mathrm{B}}$ & $5.79 \pm 0.27^{\mathrm{B}}$ & $6.09 \pm 0.50^{B}$ \\
\hline
\end{tabular}

\footnotetext{
${ }^{1)} \mathrm{RS} 1 \sim \mathrm{RS} 5$ refer to the names of the random sample group.

2) "Month" means the purchasing time.

${ }^{3}$ The values are the mean \pm SD.

4)a-d Means in a row not followed by the same letter are significantly differ $(p<0.05)$.

${ }^{5} \mathrm{~A}-\mathrm{E}$ Means in a column row not followed by the same letter are significantly differ $(\mathrm{p}<0.05)$.

" "Summer" means June and August.

7)"Winter" means February and December.
}

대표적인 역할로 알려져 있다(22,23). 총 페놀 함량은 플라 보노이드나 안토시아닌 등과 같은 화합물의 총량을 의미하 는데(24), 무 새싹채소 추출물은 총 페놀 함량이 높고, 항산 화 활성이 높게 나타나 식품첨가물이나 보존제 등의 기능성 소재로 활용될 가능성이 있는 것으로 알려져 있다(25). 본 연구에서 무 새싹채소의 총 페놀 함량은 평균 15.86 17.96 $\mathrm{GAE} \mathrm{mg} / \mathrm{g}$ 으로 나타났다. 본 연구에서 무 새싹채소의 총 페놀 함량은 평균 15.86 17.96 GAE mg/g으로 나타났으며, 월별 총 페놀함량간의 유의적인 차이는 나타나지 않았다
(Table 3). 계절별 비교에서도 모든 시료에서 여름과 겨울의 함량간의 유의차가 나타나지 않아 총 페놀함량은 구매 시기 에 영향을 받지 않는 것으로 판단되었다.

\section{총 카로티노이드}

카로티노이드는 노란색 또는 붉은색을 내는 천연 색소 로, 동-식물 뿐만 아니라 미생물에도 존재한다. 일부 카로티 노이드는 비타민 $\mathrm{A}$ 의 전구체로서 망막질환, 백내장, 심장 병 및 암 등을 예방하는 효과가 있다고 알려져 있으며, 그 
Table 3. Total phenolic contents of bimonthly and seasonal radish sprouts

\begin{tabular}{|c|c|c|c|c|c|c|c|}
\hline & & \multicolumn{6}{|c|}{ Total phenolic contents $\left(\mathrm{GAE}^{1)} \mathrm{mg} / \mathrm{g}\right.$, dry weight) } \\
\hline & & $\mathrm{RS}^{2)}$ & RS2 & RS3 & RS4 & RS5 & Mean $^{3)}$ \\
\hline \multirow{7}{*}{ Month $^{3)}$} & Feb. & $16.38 \pm 0.31^{4 / 2 \mathrm{ab} 5) \mathrm{AB} 6)}$ & $16.03 \pm 0.76^{6 B}$ & $17.47 \pm 0.36^{\mathrm{aA}}$ & $15.30 \pm 0.19^{\mathrm{bC}}$ & $14.12 \pm 1.39^{\mathrm{cD}}$ & $17.70 \pm 1.18^{\mathrm{A}}$ \\
\hline & Apr. & $16.07 \pm 0.24^{\mathrm{cB}}$ & $16.16 \pm 0.15^{\mathrm{cB}}$ & $17.33 \pm 0.04 \mathrm{bA}$ & $17.36 \pm 0.06^{\mathrm{bA}}$ & $19.84 \pm 0.45^{\mathrm{aA}}$ & $15.86 \pm 1.25^{\mathrm{A}}$ \\
\hline & Jun. & $15.68 \pm 0.97^{\mathrm{bB}}$ & $13.43 \pm 0.50^{\mathrm{cC}}$ & $16.19 \pm 0.17^{\mathrm{bA}}$ & $16.61 \pm 0.02^{\mathrm{bB}}$ & $18.32 \pm 0.18^{\mathrm{aB}}$ & $17.35 \pm 1.52^{\mathrm{A}}$ \\
\hline & Aug. & $17.21 \pm 0.03^{\mathrm{bA}}$ & $17.04 \pm 0.06^{\mathrm{bA}}$ & $17.22 \pm 0.19^{\mathrm{bA}}$ & $17.81 \pm 0.46^{\mathrm{abA}}$ & $19.01 \pm 0.53^{\mathrm{aAB}}$ & $17.96 \pm 4.96^{\mathrm{A}}$ \\
\hline & Oct. & $15.80 \pm 0.30^{\mathrm{cB}}$ & $15.89 \pm 0.06^{\mathrm{cB}}$ & $16.67 \pm 0.16^{\mathrm{bA}}$ & $17.39 \pm 0.45^{\mathrm{aA}}$ & $15.81 \pm 0.14^{\complement \mathrm{C}}$ & $17.66 \pm 0.81^{\mathrm{A}}$ \\
\hline & Dec. & $17.24 \pm 0.49^{\mathrm{bA}}$ & $17.26 \pm 0.07^{\mathrm{bA}}$ & $16.64 \pm 0.29^{\mathrm{cA}}$ & $17.64 \pm 0.14^{\mathrm{bA}}$ & $19.70 \pm 0.14^{\mathrm{aA}}$ & $16.31 \pm 0.71^{\mathrm{A}}$ \\
\hline & Mean & $16.40 \pm 0.69^{\mathrm{ab}}$ & $15.97 \pm 1.36^{b}$ & $16.92 \pm 0.50^{\mathrm{ab}}$ & $17.02 \pm 0.94^{\mathrm{ab}}$ & $17.80 \pm 2.32^{\mathrm{a}}$ & $16.82 \pm 0.69$ \\
\hline \multirow{2}{*}{ Season } & Summer $^{7}$ & $16.45 \pm 1.08^{\mathrm{A}}$ & $15.24 \pm 2.55^{\mathrm{A}}$ & $16.71 \pm 0.73^{\mathrm{A}}$ & $17.21 \pm 0.85^{\mathrm{A}}$ & $18.67 \pm 0.49^{\mathrm{A}}$ & $16.85 \pm 1.55^{\mathrm{A}}$ \\
\hline & Winter $^{8)}$ & $16.81 \pm 0.61^{\mathrm{A}}$ & $16.65 \pm 0.87^{\mathrm{A}}$ & $17.06 \pm 0.59^{\mathrm{A}}$ & $16.47 \pm 1.65^{\mathrm{A}}$ & $16.91 \pm 3.95^{\mathrm{A}}$ & $16.78 \pm 1.50^{A}$ \\
\hline
\end{tabular}

${ }^{1)} \mathrm{GAE}$ means the gallic acid equivalent.

${ }^{2)} \mathrm{RS} 1 \sim \mathrm{RS} 5$ refer to the names of the random sample group.

${ }^{3)}$ "Month" means the purchasing time.

${ }^{4}$ The values are the mean $\pm \mathrm{SD}$.

${ }^{5 \text { )ac }}$ Means in a row not followed by the same letter are significantly differ $(\mathrm{p}<0.05)$.

${ }^{6 A-D}$ Means in a column row not followed by the same letter are significantly differ $(\mathrm{p}<0.05)$.

7) "Summer" means June and August.

8)"Winter" means February and December

Table 4. Total carotenoid contents of bimonthly and seasonal radish sprouts

\begin{tabular}{|c|c|c|c|c|c|c|c|}
\hline & & \multicolumn{6}{|c|}{ Total carotenoid contents ( $\beta$-carotene $\mathrm{mg} / \mathrm{g}$, dry weight) } \\
\hline & & $\mathrm{RS}^{1)}$ & RS2 & RS3 & RS4 & RS5 & Mean \\
\hline \multirow{7}{*}{ Month $^{2)}$} & Feb. & $12.14 \pm 0.95^{3(3) 4 A 5)}$ & $12.74 \pm 0.10^{\mathrm{bA}}$ & $13.51 \pm 0.10^{\mathrm{cA}}$ & $12.71 \pm 0.50^{\mathrm{bA}}$ & $12.97 \pm 0.08^{\mathrm{aB}}$ & $12.81 \pm 0.44^{\mathrm{A}}$ \\
\hline & Apr. & $6.45 \pm 0.88^{\mathrm{cD}}$ & $7.93 \pm 0.11^{\mathrm{bD}}$ & $9.02 \pm 0.10^{\mathrm{aD}}$ & $8.24 \pm 0.11^{\mathrm{bC}}$ & $8.80 \pm 0.22^{\mathrm{aD}}$ & $8.09 \pm 1.01^{\mathrm{C}}$ \\
\hline & Jun. & $8.09 \pm 1.20^{\mathrm{cC}}$ & $10.58 \pm 2.19^{\mathrm{bB}}$ & $11.20 \pm 0.89^{\mathrm{abC}}$ & $11.91 \pm 0.15^{\mathrm{abB}}$ & $12.66 \pm 0.61^{\mathrm{aBC}}$ & $10.89 \pm 1.75^{\mathrm{B}}$ \\
\hline & Aug. & $8.65 \pm 0.43^{\mathrm{bC}}$ & $9.26 \pm 0.22^{\mathrm{aC}}$ & $9.27 \pm 0.07^{\mathrm{aD}}$ & $7.58 \pm 0.61^{\mathrm{cD}}$ & $8.33 \pm 0.24^{6 \mathrm{E}}$ & $8.62 \pm 0.71^{\mathrm{C}}$ \\
\hline & Oct. & $11.01 \pm 0.22^{\mathrm{bB}}$ & $12.29 \pm 0.03^{\mathrm{aA}}$ & $11.26 \pm 0.40^{\mathrm{bC}}$ & $12.12 \pm 0.10^{\mathrm{aB}}$ & $12.25 \pm 0.54^{\mathrm{aC}}$ & $11.78 \pm 0.60^{\mathrm{AB}}$ \\
\hline & Dec. & $8.60 \pm 0.23^{\mathrm{dC}}$ & $12.96 \pm 0.30^{\mathrm{bA}}$ & $11.86 \pm 0.06^{\mathrm{B}}$ & $11.96 \pm 0.09^{\mathrm{B}}$ & $13.59 \pm 0.17^{\mathrm{aA}}$ & $11.79 \pm 1.92^{\mathrm{AB}}$ \\
\hline & Mean & $9.16 \pm 2.07^{\mathrm{a}}$ & $10.96 \pm 2.06^{\mathrm{a}}$ & $11.02 \pm 1.68^{\mathrm{a}}$ & $10.75 \pm 2.23^{\mathrm{a}}$ & $11.43 \pm 2.27^{\mathrm{a}}$ & $10.66 \pm 0.88$ \\
\hline \multirow{2}{*}{ Season } & Summer ${ }^{6}$ & $8.37 \pm 0.40^{\mathrm{B}}$ & $9.92 \pm 0.93^{\mathrm{B}}$ & $10.24 \pm 1.36^{\mathrm{B}}$ & $9.75 \pm 3.06^{\mathrm{B}}$ & $10.50 \pm 3.06^{\mathrm{B}}$ & $9.75 \pm 0.83^{\mathrm{B}}$ \\
\hline & Winter ${ }^{7}$ & $10.37 \pm 2.50^{\mathrm{A}}$ & $12.85 \pm 0.16^{\mathrm{A}}$ & $12.69 \pm 1.17^{\mathrm{A}}$ & $12.34 \pm 0.53^{\mathrm{A}}$ & $13.28 \pm 0.44^{\mathrm{A}}$ & $12.30 \pm 1.13^{\mathrm{A}}$ \\
\hline
\end{tabular}

\footnotetext{
${ }^{1)}$ RS1 RS5 refer to the names of the random sample group.

2)"Month" means the purchasing time.

${ }^{3)}$ The values are the mean $\pm \mathrm{SD}$.

${ }^{4) \text { a-d }}$ Means in a row not followed by the same letter are significantly differ $(\mathrm{p}<0.05)$

${ }^{5 A-E}$ Means in a column row not followed by the same letter are significantly differ $(\mathrm{p}<0.05)$.

6) "Summer" means June and August.

7)"Winter" means February and December.
}

밖에도 항산화효과 등 다양한 효과를 나타내는 것으로 보고되어 있다(26,27). 무 새싹채소의 구입시기별 총 카로 티노이드 함량의 변화에 대한 결과는 Table 4 에 나타내었 다. 무 새싹채소의 총 카로티노이드 함량은 구매시기별 평 균 $8.09 \sim 12.81 \mathrm{mg} / \mathrm{g}$ 수준을 나타내었으며, 계절별 분류에 서도 겨울철이 $12.30 \pm 1.13 \mathrm{mg} / \mathrm{g}$ 으로 여름철의 $9.75 \pm 0.83$ $\mathrm{mg} / \mathrm{g}$ 에 비하여 유의적으로 높은 함량을 나타내었다. 월별 함량 비교에서는 4 월이 가장 낮은 함량을 보인 반면 2월에
는 가장 높은 함량을 나타내었으며, 전체적인 경향을 볼 때 $4,6,8$ 월이 $2,10,12$ 월에 비하여 상대적으로 낮은 총 카로티노이드 함량을 나타내었다. Kim 등(28)에서 무의 계 절별 베타카로틴 함량 분석을 통해서 가을 무에서의 함량이 $53 \mathrm{\mu g} / 100 \mathrm{~g}$ 으로 다른 계절에 비하여 가장 높은 함량을 나타낸다고 보고된 바 있어, 본 실험과 유사한 결과를 나타 난 것을 확인할 수 있었다. 
총 글루코시놀레이트 및 개별 글루코시놀레이트

글루코시놀레이트는 배추과(Brassicaceae) 작물의 독특 한 맛과 향을 만드는 고유한 기능성 물질로, 분해효소인 myrosinase와 반응하여 생성되는 isothiocyanate가 항균, 항 암효과 등을 나타내는 것으로 알려져 있어 특정 글루코시놀 레이트의 성분을 분석하고 증진시키고자 하는 육종 연구가 지속적으로 수행되어지고 있는 추세이다(29).

무 새싹채소의 구입시기별 총 글루코시놀레이트 함량의 변화에 대한 결과는 Table 5 에 나타내었다. 총 글루코시놀 레이트 함량의 구매시기별 평균은 $52.07 \sim 73.47 \mathrm{mg} / \mathrm{g}$ 수준 을 나타내었으며, 계절별 분류에서는 겨울철과 여름철의 함량에서 유의적인 차이가 나타나지 않았다. 월별 함량 비 교에서는 12 월에 $73.47 \pm 4.67$ sinigrin $\mathrm{mg} / \mathrm{g}$ 으로 가장 높은 값을 나타내었으며, 10 월에 $52.07 \pm 11.93$ sinigrin $\mathrm{mg} / \mathrm{g}$ 으로 가장 낮은 값을 나타내었다.

HPLC를 이용한 개별 글루코시놀레이트의 분석에서는 glucoraphenin, glucoerucin, glucobrassicin, gluconasturtiin이 무 새싹채소로부터 검출되었으며, 이를 개별적으로 분석하 여 그 합을 구한 결과 연중 평균이 $5.04 ~ 16.38 \mathrm{mg} / \mathrm{g}$ 수준을 나타내었다(Table 6). 개별 글루코시놀레이트의 합은 2월에 $16.38 \pm 4.43 \mathrm{mg} / \mathrm{g}$ 으로 가장 높은 값을 보였으며, 10 월에 $5.04 \pm 0.87 \mathrm{mg} / \mathrm{g}$ 으로 가장 낮은 값을 나타내었다. 총 글루코 시놀레이트의 함량 비교와 개별 글루코시놀레이트의 총 함량을 비교했을 때 일치하지 않았는데, 이는 crude한 총 글루코시놀레이트 함량을 분석한 것과, 선별된 4 개의 개별 글루코시놀레이트의 합으로 나타내는 방법적인 차이에서 발생하는 것이라고 여겨진다. 분석된 개별 글루코시놀레이 트 compounds 중에서는 glucoerucin의 함량이 가장 높게
나타났으며, glucoraphenin, gluconasturtiin, glucobrassicin 의 순서로 높은 함량을 나타냈다.

시기별 배추의 총 글루코시놀레이트 함량 변화는 봄에 수확 한 배추가 $22 \mu \mathrm{g} / \mathrm{g}$ 으로 가을에 수확한 배추가 $13 \mu \mathrm{g} / \mathrm{g}$ 인 것에 비하여 유의적으로 높게 나타낸 것으로 보고하였는데 (30), 이는 8 월과 10 월에 가장 낮은 총 글루코시놀레이트 함량을 나타낸 본 실험의 결과와 유사한 결과를 나타낸다. 또한, 순무의 총 글루코시놀레이트 함량도 5 월에 $222 \pm 32$ $\mu \mathrm{mol} / 100 \mathrm{~g}$ 으로 8 월의 $144 \pm 21 \mu \mathrm{mol} / 100 \mathrm{~g}$ 에 비하여 유의적 으로 높게 나타난 바 있다(31). 반면, Kim 등(32)은 5 7월에 수확한 신선배추가 12 4월에 수확한 신선배추에 비해 총 글루코시놀레이트 함량이 높게 나타낸 것으로 보고하였는 데, 이는 본 연구의 결과와는 상이한 것으로, 이러한 총 글루코시놀레이트 함량의 경향 차이는 Agerbirk 등(33)이 보고한 것과 같이 품종과 재배계절에 따른 차이뿐만 아니라 재배방식에 기인한 결과로 보여진다.

\section{항산화 활성}

$\mathrm{DPPH}$ 법은 항산화 물질의 전자공여능으로 인해 방향족 화합물 및 방향족 아민류에 의해 환원되어 짙은 자색을 띄는 DPPH 시약이 탈색되는 정도를 측정하는 것으로, 항산 화 능력을 나타내는 척도가 된다고 알려져 있으며, 천연소 재로부터 항산화 물질을 검색하는데 많이 이용된다 $(34,35)$. 구매시기별 DPPH 라디칼 소거능의 $\mathrm{IC}_{50}$ 값을 구한 결과는 Table 7에 나타내었다. 월 별 항산화활성을 비교하면, 2 월에 $2.51 \pm 0.47 \mathrm{mg} / \mathrm{mL}$ 로 가장 낮은 $\mathrm{IC}_{50}$ 값을 나타내어 항산화활 성이 가장 높았고, 6 월에 $4.51 \pm 0.41 \mathrm{mg} / \mathrm{mL}$ 로 가장 높은 값이 측정되어 항산화활성이 가장 낮았다. 계절별 비교에

Table 5. Total glucosinolate contents of bimonthly and seasonal radish sprouts

\begin{tabular}{|c|c|c|c|c|c|c|c|}
\hline & & \multicolumn{6}{|c|}{ Total glucosinolates contents (Sinigrin $\mathrm{mg} / \mathrm{g}$, dry weight) } \\
\hline & & $\mathrm{RS} 1^{1)}$ & $\mathrm{RS} 2$ & RS3 & RS4 & RS5 & Mean \\
\hline \multirow{7}{*}{ Month $^{2)}$} & Feb. & $78.72 \pm 0.92^{3) 44(A 5)}$ & $74.19 \pm 1.10^{\mathrm{bA}}$ & $75.18 \pm 1.65^{\mathrm{bA}}$ & $63.59 \pm 1.15^{\mathrm{cB}}$ & $48.62 \pm 1.76^{\mathrm{dC}}$ & $68.06 \pm 12.25^{\mathrm{AB}}$ \\
\hline & Apr. & $66.08 \pm 2.61^{\mathrm{bB}}$ & $60.79 \pm 1.06^{\mathrm{cB}}$ & $61.04 \pm 2.56^{\mathrm{cC}}$ & $59.65 \pm 1.20^{\circ \mathrm{C}}$ & $84.54 \pm 0.60^{\mathrm{aA}}$ & $66.42 \pm 10.43^{\mathrm{AB}}$ \\
\hline & Jun. & $66.05 \pm 1.90^{\mathrm{aB}}$ & $47.96 \pm 2.22^{\mathrm{bC}}$ & $70.90 \pm 0.38^{\mathrm{aB}}$ & $68.98 \pm 0.90^{\mathrm{aA}}$ & $70.36 \pm 5.52^{2 B}$ & $64.85 \pm 10.43^{\mathrm{AB}}$ \\
\hline & Aug. & $44.19 \pm 1.00^{\mathrm{cC}}$ & $40.75 \pm 0.25^{\mathrm{dD}}$ & $68.00 \pm 0.17^{\mathrm{aB}}$ & $61.92 \pm 2.21^{\mathrm{bBC}}$ & $44.42 \pm 1.81^{\mathrm{C}}$ & $66.81 \pm 17.64^{\mathrm{AB}}$ \\
\hline & Oct. & $67.54 \pm 9.82^{\mathrm{aB}}$ & $49.37 \pm 1.56^{\mathrm{CC}}$ & $61.02 \pm 1.27^{\mathrm{bC}}$ & $43.02 \pm 4.01^{\mathrm{dD}}$ & $39.39 \pm 7.97^{\mathrm{dD}}$ & $52.07 \pm 11.93^{\mathrm{B}}$ \\
\hline & Dec. & $69.10 \pm 1.09^{b B}$ & $75.93 \pm 3.67^{\mathrm{aA}}$ & $80.19 \pm 3.78^{\mathrm{aA}}$ & $72.74 \pm 1.42^{\mathrm{bA}}$ & $69.41 \pm 2.34^{\mathrm{bB}}$ & $73.47 \pm 4.67^{\mathrm{A}}$ \\
\hline & Mean & $67.21 \pm 7.35^{\mathrm{a}}$ & $59.84 \pm 12.63^{\mathrm{a}}$ & $73.06 \pm 11.31^{\mathrm{a}}$ & $64.88 \pm 13.08^{\mathrm{a}}$ & $61.40 \pm 16.47^{\mathrm{a}}$ & $65.28 \pm 5.22$ \\
\hline \multirow{2}{*}{ Season } & Summer ${ }^{4)}$ & $55.12 \pm 15.46^{\mathrm{B}}$ & $44.36 \pm 5.10^{B}$ & $69.45 \pm 2.05^{\mathrm{B}}$ & $65.45 \pm 4.99^{\mathrm{A}}$ & $57.39 \pm 18.34^{\mathrm{A}}$ & $55.87 \pm 12.23^{\mathrm{B}}$ \\
\hline & (inter) & $73.91 \pm 6.80^{\mathrm{A}}$ & $75.06 \pm 1.23^{\mathrm{A}}$ & $77.69 \pm 3.54^{\mathrm{A}}$ & $68.17 \pm 6.47^{\mathrm{A}}$ & $59.02 \pm 14.07^{\mathrm{A}}$ & $70.77 \pm 7.43^{\mathrm{A}}$ \\
\hline
\end{tabular}

${ }^{1)} \mathrm{RS} 1 \sim \mathrm{RS} 5$ refer to the names of the random sample group.

2)"Month" means the purchasing time.

${ }^{3)}$ The values are the mean \pm SD.

${ }^{4) a-d}$ Means in a row not followed by the same letter are significantly differ $(p<0.05)$.

${ }^{5) A-D}$ Means in a column row not followed by the same letter are significantly differ $(p<0.05)$.

6)"Summer" means June and August.

7) "Winter" means February and December. 
Table 6. Individual glucosinolate contents of monthly and seasonal radish sprouts

\begin{tabular}{|c|c|c|c|c|c|c|c|}
\hline \multirow{2}{*}{ Month $^{1)}$} & & \multicolumn{6}{|c|}{ Glucosinolates contents (mg/g, dry weight) } \\
\hline & & $\mathrm{RS}^{2)}$ & RS2 & RS3 & RS4 & RS5 & Mean \\
\hline \multirow{5}{*}{ Feb. } & Glucoraphenin & $2.04 \pm 0.12^{3) a 4) B 5}$ & $1.25 \pm 0.30^{\mathrm{bCD}}$ & $1.42 \pm 0.01^{\mathrm{C}}$ & $3.41 \pm 0.06^{\mathrm{aA}}$ & $1.16 \pm 0.01^{\mathbb{d D}}$ & $1.86 \pm 0.84^{\mathrm{A}}$ \\
\hline & Glucoerucin & $12.69 \pm 5.13^{\mathrm{aB}}$ & $11.73 \pm 6.51^{\mathrm{aB}}$ & $13.38 \pm 0.06^{\mathrm{aB}}$ & $20.52 \pm 1.90^{\mathrm{aA}}$ & $13.48 \pm 0.35^{\mathrm{bB}}$ & $14.36 \pm 3.14^{\mathrm{A}}$ \\
\hline & Glucobrassicin & $0.02 \pm 0.01^{\mathrm{cA}}$ & $0.01 \pm 0.00^{b \mathrm{~B}}$ & $0.01 \pm 0.00 \mathrm{bB}$ & $0.01 \pm 0.00^{\mathrm{CB}}$ & $0.00 \pm 0.00^{\mathrm{cC}}$ & $0.01 \pm 0.01^{\mathrm{C}}$ \\
\hline & Gluconasturtiin & $0.10 \pm 0.04^{\mathrm{bBC}}$ & $0.07 \pm 0.00^{\mathrm{CC}}$ & $0.12 \pm 0.01^{\mathrm{cdB}}$ & $0.24 \pm 0.04^{\mathrm{bA}}$ & $0.24 \pm 0.01^{\mathrm{aA}}$ & $0.15 \pm 0.07^{\mathrm{AB}}$ \\
\hline & Total $^{2)}$ & 14.83 & 13.06 & 14.93 & 24.17 & 14.87 & $16.38 \pm 4.43$ \\
\hline \multirow{5}{*}{ Apr. } & Glucoraphenin & $1.57 \pm 0.76^{\mathrm{abB}}$ & $0.80 \pm 0.33^{\mathrm{CC}}$ & $0.72 \pm 0.05^{\mathrm{eC}}$ & $2.12 \pm 0.86^{\mathrm{bB}}$ & $3.20 \pm 0.21^{\mathrm{aA}}$ & $1.68 \pm 0.92^{\mathrm{A}}$ \\
\hline & Glucoerucin & $12.19 \pm 1.00^{\mathrm{abB}}$ & $10.18 \pm 1.15^{\mathrm{aB}}$ & $6.62 \pm 2.01^{\mathrm{bC}}$ & $17.09 \pm 4.84^{\mathrm{bA}}$ & $5.75 \pm 0.06^{\mathrm{dC}}$ & $10.37 \pm 4.10^{\mathrm{AB}}$ \\
\hline & Glucobrassicin & $0.03 \pm 0.01^{\mathrm{bA}}$ & $0.02 \pm 0.01^{\mathrm{abA}}$ & $0.02 \pm 0.01^{\mathrm{abA}}$ & $0.03 \pm 0.01^{\mathrm{aA}}$ & $0.02 \pm 0.01^{\mathrm{bA}}$ & $0.02 \pm 0.00^{\mathrm{AB}}$ \\
\hline & Gluconasturtiin & $0.22 \pm 0.08^{\mathrm{aA}}$ & $0.19 \pm 0.09^{\mathrm{aA}}$ & $0.19 \pm 0.06^{\mathrm{bcA}}$ & $0.19 \pm 0.06^{\mathrm{cA}}$ & $0.15 \pm 0.06^{\mathrm{bA}}$ & $0.19 \pm 0.02^{\mathrm{A}}$ \\
\hline & Total & 14.01 & 11.18 & 7.55 & 19.42 & 9.11 & $12.26 \pm 4.68$ \\
\hline \multirow{5}{*}{ Jun. } & Glucoraphenin & $1.05 \pm 0.20^{\mathrm{bcB}}$ & $0.35 \pm 0.02^{\mathrm{dC}}$ & $1.18 \pm 0.19^{\mathrm{dB}}$ & $1.83 \pm 0.35^{\mathrm{bcA}}$ & $1.16 \pm 0.11^{\mathrm{dB}}$ & $1.11 \pm 0.47^{\mathrm{A}}$ \\
\hline & Glucoerucin & $9.03 \pm 2.80^{6 \mathrm{~B}}$ & $6.17 \pm 2.93^{\mathrm{bcC}}$ & $12.63 \pm 3.02^{\mathrm{aA}}$ & $15.15 \pm 1.05^{\mathrm{bA}}$ & $9.75 \pm 0.01^{\mathrm{cB}}$ & $10.04 \pm 2.43^{\mathrm{BC}}$ \\
\hline & Glucobrassicin & $0.03 \pm 0.01^{\mathrm{bA}}$ & $0.01 \pm 0.00^{\mathrm{bB}}$ & $0.02 \pm 0.01^{\mathrm{abAB}}$ & $0.02 \pm 0.00^{\mathrm{bAB}}$ & $0.02 \pm 0.01^{\mathrm{bcB}}$ & $0.02 \pm 0.01 B^{C}$ \\
\hline & Gluconasturtiin & $0.13 \pm 0.01^{\mathrm{bC}}$ & $0.12 \pm 0.02^{\mathrm{bcC}}$ & $0.30 \pm 0.13^{a B}$ & $0.38 \pm 0.02^{\mathrm{aA}}$ & $0.13 \pm 0.00^{\mathrm{bC}}$ & $0.20 \pm 0.08^{\mathrm{A}}$ \\
\hline & Total & 10.24 & 6.64 & 14.12 & 17.38 & 11.05 & $11.37 \pm 3.27$ \\
\hline \multirow{5}{*}{ Aug. } & Glucoraphenin & $2.10 \pm 0.72^{\mathrm{aB}}$ & $0.82 \pm 0.16^{\mathrm{cD}}$ & $2.85 \pm 0.33^{\mathrm{aA}}$ & $1.54 \pm 0.20^{\mathrm{cdC}}$ & $1.50 \pm 0.21^{\mathrm{cC}}$ & $1.76 \pm 0.68^{A}$ \\
\hline & Glucoerucin & $14.32 \pm 2.26^{\mathrm{aA}}$ & $9.83 \pm 1.18^{\mathrm{abB}}$ & $14.67 \pm 4.16^{\mathrm{aA}}$ & $8.81 \pm 1.43^{\mathrm{bB}}$ & $16.20 \pm 2.21^{\mathrm{aA}}$ & $12.79 \pm 2.93^{\mathrm{A}}$ \\
\hline & Glucobrassicin & $0.05 \pm 0.00^{\mathrm{aA}}$ & $0.03 \pm 0.00^{\mathrm{aB}}$ & $0.03 \pm 0.01^{\mathrm{aBC}}$ & $0.01 \pm 0.00^{\mathrm{cC}}$ & $0.05 \pm 0.03^{\mathrm{aA}}$ & $0.03 \pm 0.01^{\mathrm{A}}$ \\
\hline & Gluconasturtiin & $0.20 \pm 0.01^{\mathrm{aB}}$ & $0.16 \pm 0.04^{\mathrm{abB}}$ & $0.19 \pm 0.04^{\mathrm{bcB}}$ & $0.14 \pm 0.03^{\mathrm{cB}}$ & $0.28 \pm 0.07^{\mathrm{aA}}$ & $0.19 \pm 0.05^{\mathrm{A}}$ \\
\hline & Total & 16.67 & 10.84 & 17.74 & 10.5 & 18.03 & $14.78 \pm 3.79$ \\
\hline \multirow{5}{*}{ Oct. } & Glucoraphenin & $0.95 \pm 0.13^{\mathrm{cC}}$ & $1.05 \pm 0.01^{\mathrm{bcB}}$ & $1.06 \pm 0.01^{\mathrm{dB}}$ & $0.75 \pm 0.02^{\mathrm{eD}}$ & $1.49 \pm 0.03^{\mathrm{cA}}$ & $1.06 \pm 0.24^{\mathrm{A}}$ \\
\hline & Glucoerucin & $3.78 \pm 1.82^{\mathrm{cB}}$ & $5.00 \pm 0.10^{\mathrm{cA}}$ & $2.73 \pm 0.17^{\mathrm{CC}}$ & $3.97 \pm 0.20^{\mathrm{dAB}}$ & $4.00 \pm 0.13^{\mathrm{eAB}}$ & $3.90 \pm 0.72^{\mathrm{C}}$ \\
\hline & Glucobrassicin & $0.02 \pm 0.01^{\mathrm{bcA}}$ & $0.02 \pm 0.01^{\mathrm{abA}}$ & $0.02 \pm 0.01^{\mathrm{abA}}$ & $0.02 \pm 0.00^{\mathrm{bA}}$ & $0.02 \pm 0.00^{\mathrm{bA}}$ & $0.02 \pm 0.00^{\mathrm{BC}}$ \\
\hline & Gluconasturtiin & $0.11 \pm 0.07^{\mathrm{bA}}$ & $0.11 \pm 0.08^{\mathrm{bcA}}$ & $0.05 \pm 0.00^{\mathrm{dAB}}$ & $0.05 \pm 0.03^{\mathrm{dAB}}$ & $0.02 \pm 0.00^{\mathrm{cB}}$ & $0.07 \pm 0.04^{\mathrm{B}}$ \\
\hline & Total & 4.86 & 6.17 & 3.85 & 4.79 & 5.52 & $5.04 \pm 0.87$ \\
\hline \multirow{5}{*}{ Dec. } & Glucoraphenin & $1.24 \pm 0.22^{\mathrm{bcD}}$ & $3.84 \pm 0.34^{\mathrm{aA}}$ & $1.74 \pm 0.04^{\mathrm{bC}}$ & $1.28 \pm 0.03^{\mathbb{d D}}$ & $2.10 \pm 0.12^{\mathrm{bB}}$ & $2.04 \pm 0.95^{\mathrm{A}}$ \\
\hline & Glucoerucin & $5.23 \pm 1.22^{\mathrm{CC}}$ & $10.50 \pm 1.43^{\mathrm{aA}}$ & $7.32 \pm 0.06^{6 \mathrm{~B}}$ & $9.97 \pm 0.47^{\mathrm{cA}}$ & $6.73 \pm 0.50^{\mathrm{dB}}$ & $7.95 \pm 1.99^{\mathrm{BC}}$ \\
\hline & Glucobrassicin & $0.01 \pm 0.00^{\mathrm{cA}}$ & $0.01 \pm 0.00^{\mathrm{bA}}$ & $0.01 \pm 0.00^{\mathrm{bA}}$ & $0.01 \pm 0.00^{\mathrm{cA}}$ & $0.01 \pm 0.00^{\mathrm{bcB}}$ & $0.01 \pm 0.00^{\mathrm{C}}$ \\
\hline & Gluconasturtiin & $0.12 \pm 0.03^{\mathrm{bB}}$ & $0.11 \pm 0.00^{\mathrm{bcB}}$ & $0.21 \pm 0.01^{\mathrm{bA}}$ & $0.18 \pm 0.06^{\mathrm{CA}}$ & $0.06 \pm 0.01^{\mathrm{CC}}$ & $0.14 \pm 0.05^{\mathrm{AB}}$ \\
\hline & Total & 6.6 & 14.46 & 9.28 & 11.44 & 8.89 & $10.14 \pm 2.96$ \\
\hline
\end{tabular}

${ }^{1)}$ RS1 RS5 refer to the names of the random sample group.

2)" Month" means the purchasing time.

${ }^{3)}$ The values are the mean $\pm \mathrm{SD}$.

${ }^{4) \text { a-d }}$ Means in a row not followed by the same letter are significantly differ $(\mathrm{p}<0.05)$

${ }^{5 A-D}$ Means in a column row not followed by the same letter are significantly differ $(\mathrm{p}<0.05)$.

Table 7. DPPH radical scavenging activity about bimonthly and seasonal radish sprouts

\begin{tabular}{|c|c|c|c|c|c|c|c|}
\hline & \multicolumn{6}{|c|}{ DPPH radical scavenging $\left(\mathrm{IC}_{50}{ }^{1)}\right.$ values, $\mathrm{mg} / \mathrm{mL}$ ) } \\
\hline & & $\mathrm{RS}^{2)}$ & RS2 & RS3 & RS4 & RS5 & Mean \\
\hline \multirow{7}{*}{ Month3) } & Feb. & $2.29 \pm 0.28^{4 / 25)(\mathrm{E})}$ & $2.42 \pm 0.11^{\mathrm{abE}}$ & $3.01 \pm 0.25^{\mathrm{aC}}$ & $2.94 \pm 0.36^{\mathrm{aCD}}$ & $1.87 \pm 0.30^{b D}$ & $2.51 \pm 0.47^{\mathrm{C}}$ \\
\hline & Apr. & $3.47 \pm 0.07^{\mathrm{B}}$ & $3.51 \pm 0.06^{\mathrm{aBC}}$ & $2.74 \pm 0.07^{\mathrm{cC}}$ & $3.05 \pm 0.00^{\mathrm{BBC}}$ & $2.02 \pm 0.05^{\mathrm{dD}}$ & $2.96 \pm 0.61^{\mathrm{BC}}$ \\
\hline & Jun. & $4.41 \pm 0.22^{\mathrm{bA}}$ & $5.04 \pm 0.05^{\mathrm{aA}}$ & $4.49 \pm 0.00^{\mathrm{aA}}$ & $4.67 \pm 0.07^{\mathrm{aA}}$ & $3.92 \pm 0.30^{\mathrm{cD}}$ & $4.51 \pm 0.41^{\mathrm{A}}$ \\
\hline & Aug. & $3.47 \pm 0.36^{\mathrm{aBC}}$ & $3.22 \pm 0.35^{\mathrm{aD}}$ & $3.25 \pm 0.62^{\mathrm{aC}}$ & $3.21 \pm 0.05^{\mathrm{aBC}}$ & $2.05 \pm 0.29^{\mathrm{bA}}$ & $3.04 \pm 0.56^{\mathrm{BC}}$ \\
\hline & Oct. & $2.86 \pm 0.01^{\mathrm{aDE}}$ & $3.16 \pm 0.21^{\mathrm{aCD}}$ & $2.97 \pm 0.31^{\mathrm{aC}}$ & $2.45 \pm 0.12^{\mathrm{bD}}$ & $2.54 \pm 0.05^{\mathrm{bC}}$ & $2.79 \pm 0.30^{\mathrm{BC}}$ \\
\hline & Dec. & $2.84 \pm 0.30^{\mathrm{bCD}}$ & $3.52 \pm 0.02^{\mathrm{aB}}$ & $3.70 \pm 0.39^{\mathrm{aB}}$ & $3.64 \pm 0.41^{\mathrm{abB}}$ & $3.07 \pm 0.67^{\mathrm{bB}}$ & $3.35 \pm 0.38^{\mathrm{B}}$ \\
\hline & Mean & $3.22 \pm 0.73^{\mathrm{a}}$ & $3.48 \pm 0.86^{\mathrm{a}}$ & $3.36 \pm 0.64^{\mathrm{a}}$ & $3.33 \pm 0.76^{\mathrm{a}}$ & $2.58 \pm 0.79^{\mathrm{a}}$ & $3.19 \pm 0.36$ \\
\hline \multirow{2}{*}{ Season } & Summer $^{7}$ & $3.94 \pm 0.66^{\mathrm{A}}$ & $4.13 \pm 1.29^{A}$ & $3.87 \pm 0.88^{\mathrm{A}}$ & $3.94 \pm 1.03^{\mathrm{A}}$ & $2.99 \pm 1.32^{\mathrm{A}}$ & $3.77 \pm 0.45^{\mathrm{A}}$ \\
\hline & Winter $^{8)}$ & $2.57 \pm 0.39^{\mathrm{B}}$ & $2.97 \pm 0.78^{\mathrm{B}}$ & $3.36 \pm 0.49^{\mathrm{A}}$ & $3.29 \pm 0.49^{B}$ & $2.47 \pm 0.85^{\mathrm{A}}$ & $2.93 \pm 0.41^{\mathrm{B}}$ \\
\hline
\end{tabular}

${ }^{1)} \mathrm{IC}_{50}$ refer to the inhibitory concentration.

${ }^{2} \mathrm{RS} 1 \sim \mathrm{RS} 5$ refer to the names of the random sample group.

3)"Month" means the purchasing time.

${ }^{4}$ The values are the mean $t \mathrm{SD}$.

5)ad Means in a row not followed by the same letter are significantly differ $(\mathrm{p}<0.05)$.

6A-EMeans in a column row not followed by the same letter are significantly differ $(\mathrm{p}<0.05)$.

7) "Summer" means June and August.

8)"Winter" means February and December. 
서 겨울이 여름보다 항산화 활성이 높게 나타났는데, 이는 Ulva rigida의 DPPH 라디칼 소거능이 8 10월에 비해 2, 3월에 높게 나타났다는 보고(36)와 유사한 경향을 보이며, 이를 통해 온도가 비교적 낮은 시기에 항산화 활성이 높아 짐을 알 수 있었다.

\section{요 약}

본 연구는 국내에서 생산·유통되는 무 새싹채소의 미생 물 및 영양학적 품질지표를 조사하기 위하여 2개월에 한번 씩 무 새싹채소를 구매한 후, 미생물 오염도, 총 페놀함량, 총 카로티노이드 함량, 총 글루코시놀레이트 함량 및 개별 글루코시놀레이트 화합물을 분석하고, 항산화활성을 측정 해보았다. 일반세균수와 대장균군수는 평균 $7.45 \pm 0.73 \mathrm{log}$ $\mathrm{CFU} / \mathrm{g}$ 과 $6.55 \pm 0.61 \log \mathrm{CFU} / \mathrm{g}$ 을 나타내었으며, 겨울철에 는 각각 $6.70 \pm 0.61 \log \mathrm{CFU} / \mathrm{g}$ 과 $6.09 \pm 0.50 \log \mathrm{CFU} / \mathrm{g}$ 으로 낮았고, 여름철에는 각각 $7.91 \pm 0.15 \log \mathrm{CFU} / \mathrm{g}$ 과 $6.94 \pm 0.17$ $\log \mathrm{CFU} / \mathrm{g}$ 으로 높은 오염도를 나타내었다. 총 페놀함량은 평균 $16.82 \pm 0.69 \mathrm{mg} / \mathrm{g}$ 을 나타내었으며 구매시기별 유의차 는 없는 것으로 확인되었다. 총 카로티노이드 함량은 평균 값이 $10.73 \pm 2.08 \mathrm{mg} / \mathrm{g}$ 로, 계절별로 비교했을 때 겨울이 여 름보다 높은 함량을 나타내었다. 총 글루코시놀레이트 함 량은 평균 $65.80 \pm 12.68 \mathrm{mg} / \mathrm{g}$ 이었으며, 12 월에 $73.47 \pm 4.67$ $\mathrm{mg} / \mathrm{g}$ 으로 가장 높은 함량을 보였으나, 구매시기에 따른 유의적인 차이는 나타나지 않았다. 개별 글루코시놀레이트 함량은 glucoerucin, glucoraphenin, gluconasrutiin, glucobrassicin의 순서로 높게 나타내었으며, glucoerucin을 제외한 성분들은 구매시기에 따른 성분함량에서 유의적 차이를 나타내지는 않았다. 항산화 활성은 DPPH 라디컬 소거능으로 측정하였는데, 2월에 가장 높고 6 월에 가장 낮 은 항산화 활성을 보여, 겨울철이 여름철에 비해 항산화활 성이 높은 것을 알 수 있었다. 따라서, 무 새싹채소의 미생물 오염도, 총 카로티노이드 함량 및 항산화 활성은 구매시기 에 따라 함량 및 활성의 변화를 보였으나, 총 페놀 함량, 총 글루코시놀레이트는 구매시기별 유의적인 차이 없음을 확인할 수 있었다.

\section{References}

1. Choi JW, Park SY, Yeon JH, Lee MJ, Chung DH, Lee KH, Kim MG, Lee DH, Kim KS, Ha SD (2005) Microbial contamination levels of fresh vegetables distributed in markets. J Food Hyg Safety, 20, 43-47

2. Cho SK, Park JH (2012) Biocontrol of sprouts through ethanol and organic acids. Korean J Food Nutr, 25,
149-155

3. Kim IS, Han SH, Han KW (1997) Study on the chemical change of amino acid and vitamin of rapeseed during germination. J Korean Soc Food Sci Nutr, 26, 1058-1062

4. Song MR (2001) Volatile flavor components of cultivated radish (Raphanus sativa L.) sprout. Korean J Food Nutr, 14, 20-27

5. Lee YA, Kim HY, Cho EJ (2005) Comparison of methanol extracts from vegetables on antioxidative effect under in vitro and cell system. Korean J Soc Food Sci Nutr, 34, 1151-1156

6. Kylen AM, McCready RM (1975) Nutrients in seeds and sprouts of alfalfa, lentils, mung beans and soybeans. J Food Sci, 40, 1008-1009

7. Paul RH, David MB (2011) Phytochemical composition and biological activity of 8 varieties of radish (Raphanus sativis L.) sprouts and mature taproots. J Food Sci, 76, 185-192

8. Jagdish S, Rai M, Upadhyay AK, Bahadur A, Chaurasia SNS, Sing KP (2006) Antioxidant phytochemicals in broccoli (Brassica oleracea var. italica Plenck) cultivars. J Food Sci Technol, 43, 391-393

9. Robertson LJ, Johannessen GS, Gjerde BK, Loncarevic S (2002) Microbiological analysis of seed sprouts in Norway. Int J Food Microbiol, 75, 119-126

10. Han JH, Moon HK, Kim JK, Kim GY, Kang WW (2003) Changes in chemical composition of radish bud (Raphanus sativis $\mathrm{L}$.) during growth stage. Korean $\mathrm{J}$ Soc Food Cookery Sci, 19, 596-602

11. Solberg M, Buckalwe JJ, Chen CM, Schaffiner DW, O'neil K, Mcdowell J, Post LS, Boderch M (1990) Microbiological safety assurence system for food service facilities. J Food Technol, 44, 68-73

12. Kang TM, Cho SK, Park JY, Song KB, Chung MS, Park JH (2011) Analysis of microbial contamination of sprouts and fresh-cut salad in a market. Korean J Food Sci Technol, 43, 490-494

13. Park HJ, Min KJ, Park NY, Cho JI, Lee SH, Hwang IG, Heo JJ, Yoon KS (2013) Estimation on the consumption patterns of potentially hazardous foods with high consumer risk perception. Korean J Food Sci Technol, 45, 59-69

14. Park JP, Kim HW, Lee DS, Paik HD (2007) Seasonal and market group variation in the microbiological quality of seasoned soybean sprouts. Food Sci Biotechnol, 16, 325-328

15. AOAC (1995) Official Methods of Analysis. 16th ed. 
Association of Official Analytical Chemists, Washington DC, p 16-17

16. Kim HJ, Fonseca JM, Choi JH, Kubota C (2007) Effect of methyl jasmonate on phenolic compounds and carotenoids of romaine lettuce (Lactuca sativa L.). J Agric Food Chem, 55, 10366-10372

17. Kestwal RM, Lin JC, Bacal-Kestwal D, Chiang BH (2011) Glucosinolates fortification of cruciferous sprouts by sulphur supplementation during cultivation to enhance anti-cancer activity. Food Chem, 126, 1164-1171

18. LEE KC (2005) Develop a sample preparation procedure for HPLC analysis of glucosinolates on traditional chinese medicines. $\mathrm{Ph} \mathrm{D}$ Thesis, Hong Kong Baptist University, Hong Kong, p 9-12

19. Lee JM, Chang PS, Lee JH (2007) Comparison of oxidative stability for the thermally-oxidized vegetable oils using a DPPH method. Korean J Food Sci Technol, 39, 133-137.

20. Lee JH (2012) Microbial contamination of commonly consumed vegetables and sprouts in Korea. MS Thesis, Korea University, Korea, p 44

21. Jo MJ, Jeong AR, Kim HJ, Oh SW, Kim YJ (2011) Microbiological quality of fresh-cut produce and organic vegetables. Korean J Food Sci Technol, 43, 91-97

22. Whang HJ, Han WS, Yoon KR (2001) Quantitative analysis of total phenolic content in apple. Anal Sci Technol, 14, 377-383

23. Cheigh HS, Lee CY (1993) Antioxidative characteristics of plant phenolic compounds. Life Sci, 3, 9-17

24. Kim HS, Hong MJ, Kang IY, Jung JY, Kim HK, Shin YS, Jun HJ, Suh JK, Kang YH (2009) Radical scavenging activities and antioxidant constituents oriental melon extract. J Bio-Environment Cont, 18, 442-447

25. Han JH, Moon HK, Chung SK, Kang WW (2013) Comparison of antioxidant activities of radish bud (Raphanus sativus L.) according to extraction solvents and sprouting period. J Korean Soc Food Sci Nutr, 42, 1767-1775

26. Jo JO, Jung IC (2000) Changes in carotenoid contents of several green-yellow vegetables by blanching. Korean J Food Cookery Sci, 16, 17-21

27. Kim JB, Ha SH, Lee JY, Kim HH, Yoon SH, Kim YH
(2003) Biological activities and analysis of carotenoids in plants. Korean J Crop Sci, 48(S), 72-78

28. Kim MJ, Kim JH, Oh HK, Chang MJ, Kim SH (2007) Seasonal variation of nutrients in Korean fruits and vegetables : examining water, protein, lipid, ascorbic acid, and $\beta$-carotene contents. Korean J Food Cookery Sci, 23, 423-432

29. Lee JG, Kwak JH, Um YC, Lee SG, Jang YA, Choi CS (2012) Variation of glucosinolate contents among domestic broccoli (Brassica oleacea L. var. italica) accessions. Korean J Hort Sci Technol, 30, 743-750

30. Cartea ME, Velasco P, Obregon S, Padilla G, de Haro A (2008) Seasonal variation in glucosinolate content in Brassica oleracea crops grown in northwestern spain. Phytochem, 69, 403-410

31. Justen VL, Fritz VA, Cohen JD (2012) Seasonal variation in glucosinolate accumulation in turnips grown under photoselective nettings. Hortic Environ Biotechnol, 53, 108-115

32. Kim MK, Hong EY, Kim GH (2010) Change of total glucosinolates level according to processing treatments in Chinese cabbage (Brassica campestris L. ssp. Pekinensis) from different harvest seasons. Korean J Hort Sci Technol, 28, 593-599

33. Agerbirk N, Olsen CE, Nielsen JK (2001) Seasonal variation in leaf glucosinolates and insect resistance in two types of Barbarea vulgaris ssp. arcuata. Phytochem, 58, 91-100

34. Kang MH, Choi CS, Kim ZS, Chung HK, Min KS, Park CG, Park HW (2002) Antioxidative activities of ethanol extract prepared from leaves, seed, branch and aerial part of Crotalaria sessiflora L. Korean J Food Sci Technol, 34, 1098-1102

35. Yu MH, Im HG, Lee HJ, Ji YJ, Lee IS (2006) Components and their antioxidative activities of methanol extracts from sarcocarp and seed of Zizyphus jujuba var. inermis Rehder. Korean J Food Sci Technol, 38, 128-134

36. Trigui M, Gasmi L, Zouari I (2013) Seasonal variation in phenolic composition, antibacterial and antioxidant activities of Ulva rigida (Chlorophyta) and assessment of antiacetylcholinesterase potential. J Appl Phycol, 25, 319-328 